\title{
血液透析患者においてフェキソフェナジンの服用により ジゴキシンの血清中濃度が低下した症例
}

\author{
西田愛子 ${ }^{1}$, 三宅健文 ${ }^{12}$, 辻本雅之 ${ }^{* 1}$, 今田直樹 ${ }^{3}$, \\ 青木 正 $^{3}$, 高良恒史 ${ }^{1}$, 横山照由 ${ }^{1}$ \\ 京都薬科大学病院薬学分野 1 \\ 社会福祉法人京都社会事業財団西陣病院薬斉科 ${ }^{2}$ \\ 社会福祉法人京都社会事業財団西陣病院透析センター ${ }^{3}$

\section{Co-administration of Fexofenadine Reduces \\ Serum Digoxin Concentration in \\ Patient Undergoing Hemodialysis}

\author{
Aiko Nishida ${ }^{1}$, Takefumi Miyake ${ }^{1,2}$, Masayuki Tsujimoto ${ }^{* 1}$, Naoki Imada ${ }^{3}$, \\ Tadashi Aoki $^{3}$, Kohji Takara ${ }^{1}$ and Teruyoshi Yokoyama ${ }^{1}$ \\ Department of Hospital Pharmacy, Faculty of Pharmaceutical Science, \\ Kyoto Pharmaceutical University ${ }^{1}$ \\ Department of Hospital Pharmacy, Nishijin Hospital ${ }^{2}$ \\ Department of Hemodialysis, Nishijin Hospital ${ }^{3}$ \\ $\left[\begin{array}{l}\text { Received May 8, } 2007 \\ \text { A ccepted November 5, } 2007\end{array}\right]$
}

A 60-year-old male was diagnosed with a polycystic kidney disease, and maintenance hemodialysis was initiated on an outpatient basis in February 2002. In February 2004, he was started on $0.125 \mathrm{mg} /$ day of digoxin three times a week after hemodialysis. Later, $60 \mathrm{mg}$ of fexofenadine twice daily was co-administered with the digoxin during 2 periods: A ugust 7 to September 28, 2004 (Period A) and A pril 13 to December 20, 2005 (Period B).

The trough concentration of digoxin tended to be lower in Period $A$, and the trough concentration of digoxin, which was $1.0 \mathrm{ng} / \mathrm{mL}$ just before Period $B$, decreased gradually to a level less than the limit of detection $(0.3 \mathrm{ng} / \mathrm{mL})$ in around 4 months. This decrease was maintained for at least 3 months after discontinuing the administration of fexofenadine. Blood samples were collected before hemodialysis, and the serum concentration of digoxin was measured once a month by enzyme immunoassay. Drugs known to decrease serum digoxin concentrations were not administered during the surveillance period.

In conclusion, our findings suggest that the co-administration of fexofenadine with digoxin could decrease the serum concentration of digoxin in patients undergoing hemodialysis.

Key words — renal failure, drug interaction, digoxin, fexofenadine, pharmacokinetics, nonrenal clearance

\section{緒言}

近年, わが国では維持透析患者が飛躍的に増大し， 2005 年度には 25 万人を突破している11.これは, わが 国の本格的な高齢社会への突入ならびに慢性腎臓病の原 因の一つである糖尿病患者の急増により，今後も増加し ていくことは明白である .
透析患者での薬物体内動態は, 腎クリアランスの低下 のみならず，蛋白結合率の低下・肝クリアランスの上昇 および低下のように多樣に変化している2).この変化 は, 薬物単独投与時における体内動態の変化だけでな く, 薬物相互作用の有無および強弱にまで影響を及ぼす と考えられる．実際に，腎機能正常患者では併用注意で あるジゴキシンとクラリスロマイシンの相互作用が , 透 析患者ではクラリスロマイシンの併用により血清中ジゴ 
キシン濃度が 4 倍にも上昇する症例が報告されてい る ${ }^{3}$. 以上のことから，透析患者における薬物相互作用 を調査し，情報を蓄積することは非常に重要である．

透析患者における死因の第一位である心不全に対し て，強心薬ジゴキシンがしばしば選択される . ジゴキシ ンは, 腎排泄型薬物であるが， $0.125 \mathrm{mg}$ を週に 3〜4回 透析後に服用することで, 透析患者においても安定した 血清中濃度を得ることが可能である4) ンは他の強心薬と異なり心不全の予後を悪化させないた め5)，透析患者でも高い使用頻度となっている．

一方，季節性アレルギ一症状や透析患者に頻発する皮 膚掻痒症に対して抗アレルギー薬が使用されることがあ る、中でも，フェキソフェナジンは，副作用である中枢 抑制が少ないことから汎用されている゙。 者の皮膚掻㾕症に対しても有効であることから”，透析 患者において使用頻度の高い薬物の一つである．

今回，ジゴキシン服用中の維持透析患者において， フェキソフェナジンの併用時にジゴキシンの血清中濃度 が低下した症例を経験したので報告する．

\section{症例}

症例 1

60 歳男性，身長 $165 \mathrm{~cm}$ ，体重 $57 \mathrm{~kg}$

原疾患 : 多発性囊胞腎

現病歴：うつ血性心不全，不整脈，アレルギ一性鼻炎 透析条件: 週 3 回通院 4時間, 血液透析(Hemo Dialy-

sis : HD)

主な併用薬(1日量)：フロセミド $80 \mathrm{mg}$, 一硝酸イソソ

ルビド $40 \mathrm{mg}$, 炭酸カルシウム $1.5 \mathrm{~g}$, 炭酸水素ナト

リウム $2 \mathrm{~g}$ ，消化酵素製剂 $0.9 \mathrm{~g}$ ，イルソグラジン $4 \mathrm{mg}$ 2004 年 2 月よりうっ血性心不全に対する治療として ジゴキシンの服用を開始した患者は, 1 回 $0.125 \mathrm{mg}$ を 週に 3 回投与(透析終了後)することにより良好な血清中 濃度を示した(トラフ濃度 0.6 0.9 ng $/ \mathrm{mL}$ ) . しかしなが ら，2004年 8月 7 日から 2004年 9 月 28日の間(期間 A)，アレルギー性鼻炎に対する治療薬としてフェキソ フェナジンが投与され，弚の期間ジゴキシンの血清中濃 度は低下傾向を示した(トラフ濃度 $0.5 \mathrm{ng} / \mathrm{mL}$ ) . 症状の 改善がみられたため，2004年 9 月 28 日にフェキソフェ ナジンの服用を一度中止した . 光の後 , ジゴキシンの血 清中濃度は徐々に回復し，2004年 10 月 12 日には 0.6 $\mathrm{ng} / \mathrm{mL} ， 2005$ 年 1月 11 日には $0.8 \mathrm{ng} / \mathrm{mL} ， 2005$ 年 3 月 15 日は $1.0 \mathrm{ng} / \mathrm{mL}$ と併用前の水準にまで回復した．し かし，アレルギー性鼻炎の症状が発現したため，2005 年 4 月 13 日にフェキソフェナジンの服用を再開( 2005 年 12 月 20 日 ; 期間B)した. 弚の後, ジゴキシンの血 清中濃度は徐々に低下し, 4 カ月後の 2005 年 8 月 9 日
に, 定量限界 $(0.3 \mathrm{ng} / \mathrm{mL})$ 以下まで低下した(図 1). なお，血清中ジゴキシン濃度を低下させることが明らか な薬剂は，観察期間を通して併用されておらず，心不全 の病態および患者の生理機能(肝機能, 血清カリウム値 など)にも顕著な変化は認められなかった．また，血清 中ジゴキシン濃度は, 毎月 1 回火曜日の透析前に採血(最 終服用 68 時間後)し，SRL 社に測定を依頼した(酢素免 疫測定法; 定量限界 $0.3 \mathrm{ng} / \mathrm{mL}$ ).

本症例では, ジゴキシンは看護師管理下, 透析終了後 に服用しているため，担当看護師によりコンプライアン スが完全であることを確認している .

症例 2

71 歳女性，身長不明，体重 $42 \mathrm{~kg}$

原疾患 : 慢性系球体腎炎

現病歴：発作性心房細動，うつ血性心不全

透析条件：週 3 回通院 4時間, HD

主な併用薬(1日量)：フロセミド $160 \mathrm{mg}$ ，ランソプラ ゾール $30 \mathrm{mg}$,カルベジロール $2.5 \mathrm{mg}$, サルポグレラー 卜 $300 \mathrm{mg}$ ， イルソグラジン $4 \mathrm{mg}$, ニコランジル 10 $\mathrm{mg}$, ,クロルフェニラン $6 \mathrm{mg}$,ドロキシドパ $200 \mathrm{mg}$, 炭酸カルシウム $1.5 \mathrm{~g}$, 炭酸水素ナトリウム $2 \mathrm{~g}$

1998年 7 月より発作性心房細動に対する治療として ジゴキシンの服用を開始した患者は, 1 回 $0.0625 \mathrm{mg}$ を 週に 5 回投与することにより 1.3 1.7ng/mL という良好 なトラフ血清中濃度を示した . しかしながら，2006年 3 月 11 日に，アレルギー性結膜炎およびアレルギー性鼻 炎に対する治療薬としてフェキソフェナジンが投与開始 された後 , ジゴキシンのトラフ血清中濃度は $1.1 \mathrm{ng} / \mathrm{mL}$ に低下した .また ,フェキソフェナジンの投与終了後の ジゴキシンのトラフ血清中濃度は $2.2 \mathrm{ng} / \mathrm{mL}$ であった (図 2) . なお，血清中ジゴキシン濃度を低下させること が明らかな薬剂は，観察期間を通して併用されておら ず，心不全の病態および患者の生理機能(肝機能, 血清 カリウム值など)にも顕著な変化は認められなかった .

本症例において, ジゴキシンは予定通りに服用された ことを患者へのインタビューにより確認している．

\section{考察}

今回 , 透析患者において, ジゴキシンの血清中濃度が 低下する症例に遭遇した . 症例 1 では，血清中ジゴキシ ン濃度が低下した期間 B において , ジゴキシンの血中 濃度を低下させ得るランソプラゾールの投与中止が認め られた。胃酸分泌抑制作用を有するランソプラゾールの 投与中止に伴い, ジゴキシンの加水分解が促進され血清 中ジゴキシン濃度を低下させた可能性が考えられる．し かしながら, 胃酸分泌がランソプラゾールの投与中止 3 日後に完全に回復するにも関わらず8，投与中止後 3 力 


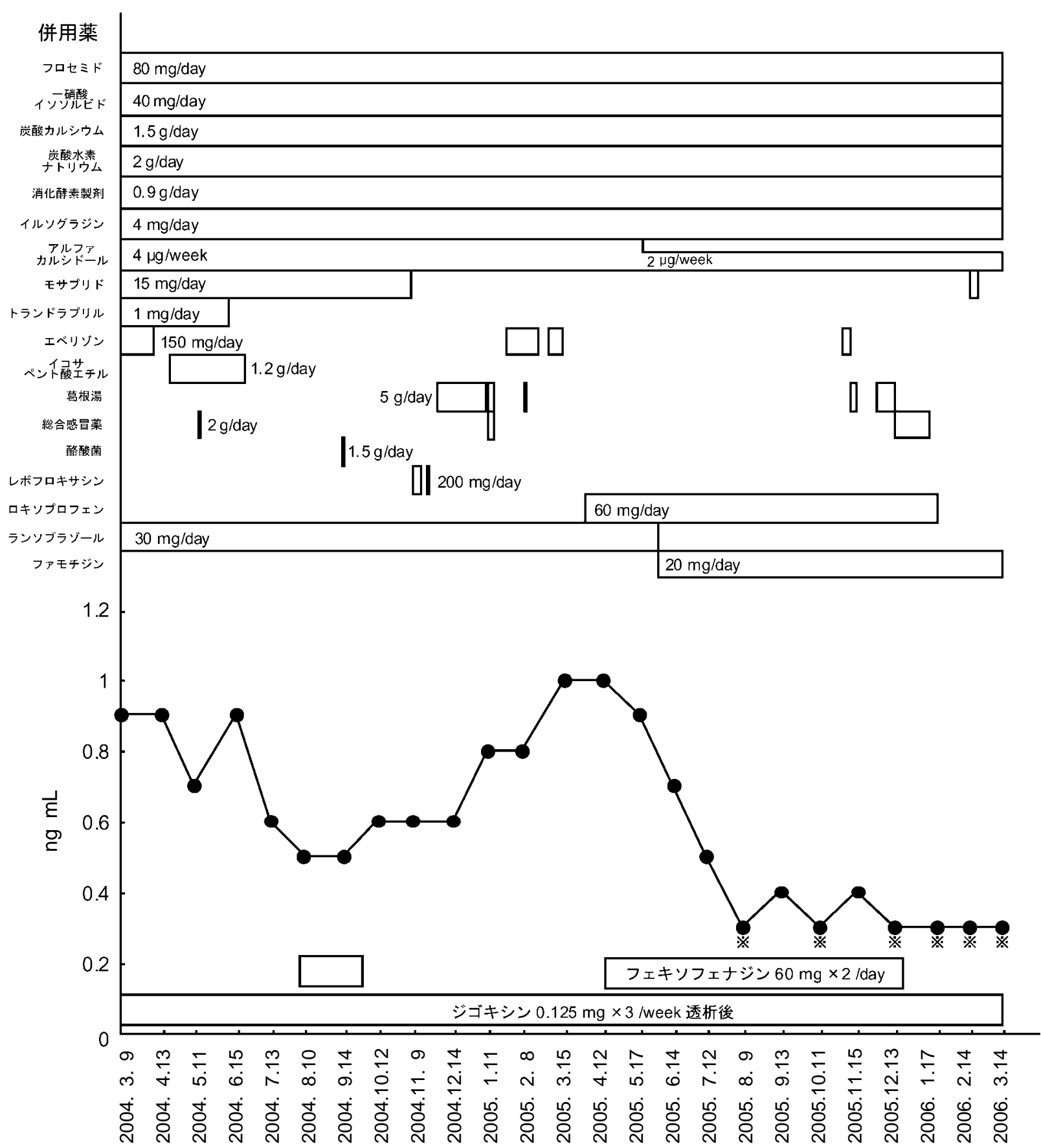

図 1 . 症例 1 における血清中ジゴキシン濃度推移と併用薬 ※は定量限界 $(0.3 \mathrm{ng} / \mathrm{mL})$ 以下を示す。

月間も血清中ジゴキシン濃度の低下が持続したことか ら，血清中ジゴキシン濃度を低下させる要因から除外出 来ると考えられた .一方, 症例 1 において, 血清中ジゴ キシン濃度が低下した期間 $\mathrm{A}$ および期間 $\mathrm{B}$ にフェキソ フェナジンが投与されていた . また, 症例 2 においても 血清中ジゴキシン濃度が低下傾向を示した時期と一致し てフェキソフェナジンが投与されていた．したがって， 今回の血清中ジゴキシン濃度の低下は, フェキソフェナ ジンの併用によると推測された .
しがしながら これまでに腎機能正常患者においても， このような相互作用例は報告されていない．この理由と して, 透析患者においてフェキソフェナジンの血中濃度 か顕著に上昇している可能性が考えられた．実際，フェ キソフェナジン単回投与時の AUC は, 腎機能低下患者 において健常者の 2 2.5倍であり，半減期も，25 時間 程度まで延長しているため9，腎機能低下患者における フェキソフェナジン連続投与時の血中濃度は顕著に上昇 していると推察される.また，通常は，腎排泄されるジ 


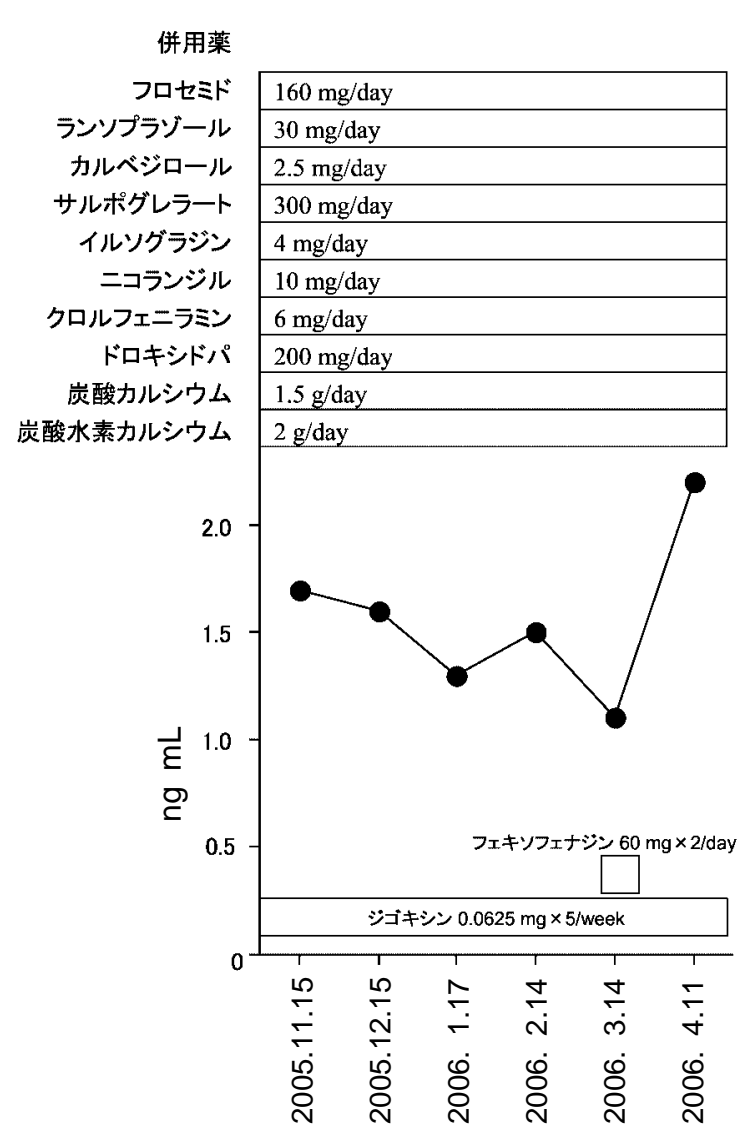

図 2 . 症例 2 における血清中ジゴキシン濃度推移

ゴキシンは, 腎機能が廃絶している透析患者においては， 肝臓を介した胆汁排泄ならびに消化管分泌が主要な排泄 経路になると考えられる.よって，フェキソフェナジン が , ジゴキシンの肝および消化管からの排泄を六進させ るならば，透析患者においてのみジゴキシンの血清中濃 度の低下として顕在化することも十分に考えられる．

ジゴキシンは, 分布容積が非常に大きな薬物である. フェキソフェナジンがジゴキシンの組織移行性を低下さ せると仮定すると，光の消失は速くなる．よって，今回 認められた相互作用は, ジゴキシンの分布低下に起因す るかも知れない .

一方で, ジゴキシンは消化管管腔側膜に常在するP 糖蛋白質(MDR 1)や肝血管側膜に高発現している Organic anion transporting polypeptide 1B 3(OATP 1B 3)に より輸送されることが知られている ${ }^{10,11}$. また , 症例 1 で認められた血清中ジゴキシン濃度の変化は, フェキソ フェナジンの投与開始および投与中止に対して速やかに 反応せず，この現象は，セント・ジョーンズワート摂取 開始および攝取中止によるCYP 3A 4/MDR 1の誘導お よび誘導解除に 3〜4週間程度要する事実と類似してい
$3^{12)}$. 以上のことから , 本症例では, フェキソフェナジ ンがMDR 1もしくはOATP 1B 3の発現を誘導した可 能性も考えられた .

結論として, 血液透析患者におけるジゴキシンの血清 中濃度はフェキソフェナジン併用により低下する可能性 が示された .

\section{引用文献}

1) 日本透析医学会統計調査委員会, わが国の慢性透析 療法の現況(2005年 12 月 31 日現在), 日本透析医学 会, 40, 1-22 (2006).

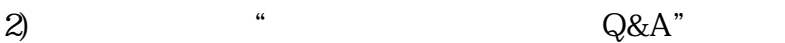
j , 2005, pp.142-183.

3) S. Hirata, S. Izumi, T. Furukubo, M. Ota, M. Fujita, T. Y amakawa, I. Hasegawa, H. Ohtani, Y. Sawada, Interactions between clarithromycin and digoxin in patients with end-stage renal disease, Int. J. Clin. Pharmacol. Ther., 43, 30-36 (2005).

4) ジゴシン®錠 $0.125 \mathrm{mg}$ 医薬品インタビューフォー 厶, 中外製薬株式会社，2005年 11 月改訂.

5) The digitalis investigation group, The effect of digoxin on mortality and morbidity in patients with heart failure, N. Eng. J. Med., 336, 525-533 (1997).

6) 田代学，櫻田幽美子, 望月秀紀, 櫻井映子, 加藤元 久, 伊藤正敏, 谷内一彦, 抗ヒスタミン薬の $\mathrm{H} 1$ 受 容体占拠率と炎の鎮静作用の関係 -フェキソフェナ ジンの臨床薬理試験 - , 臨床薬理 , 33，1635-164S (2002).

7) 金成洙, 赤松浩彦, 廣瀨悟, 四宮敏彦, 下山博身, 透析患者の皮膚掻痒症に対する塩酸フェキソフェナ ジンの効果，医薬ジャーナル，40, 988-992 (2004).

8) M. Katashima, K. Y amamoto, Y. Tokuma, T. Hata, Y. Sawada, T. Iga, Comparative pharmacokinetic/pharma codynamic analysis of proton pump inhibitors omepra zole, lansoprazole and pantoprazole, in humans, Eur. $J$. Drug Metab. Pharmacokinet., 23, 19-26 (1998).

9) アレグラ ${ }^{\circledR}$ 錠 $^{2} \mathrm{mg}$ 医薬品インタビューフォーム, サノフィ・アベンティス株式会社, 2006 年 1月改 訂.

10) G.A. Kullak-Ublick, M.G. Ismair, B. Stieger, L. Landmann, R. Huber, F. Pizzagalli, K. Fattinger, P.J. Meier, B. Hagenbuch, Organic anion-transporting polypeptide $B$ (OATP-B) and its functional comparison with three other OATPs of human liver, Gastroenterology, 120, 525-533 (2001).

11) Y. Tanigawara, Role of P-glycoprotein in drug disposition, Ther. Drug Monit., 22, 137-140 (2000).

12) Y. Murakami, T. Tanaka, H. Murakami, M. Tsujimoto, H. Ohtani, Y. Sawada, Pharmacokinetic modelling of the interaction between St John's wort and ciclosporin A, Br. J. Clin. Pharmacol ., 61, 671-676 (2006). 